\title{
PENGARUH PENDIDIKAN, PELATIHAN, DAN KOMPETENSI TERHADAP KINERJA KARYAWAN PADA CV. ENIGMA
}

\author{
Sri Mulyani
}

\begin{abstract}
ABSTRAK
Penelitian ini dilakukan kepada karyawan CV. ENIGMA menggunakan metode deskriptif kuantitatif. Instrumen pengumpul data yang digunakan adalah kuesioner tertutup dengan skala likert. Jumlah populasi sebanyak 291 orang karyawan, dengan sampel responden sebanyak 168 orang karyawan pada CV. Enigma. Data di analisis melalui perhitungan statistik dengan perangkat SPSS versi 23 for windows.

Berikut hasil penelitian yang di dapat : (1) Hasil uji t sebesar 6,512 yang kemudian dibandingkan dengan $\mathrm{t}$ tabel yaitu 1,974, yang berarti bahwa hipotesis dalam penelitian ini menolak $\mathrm{H}_{0}$ dan menerima $\mathrm{H}_{\mathrm{a} 1}$. Dengan demikian dapat disimpulkan bahwa hipotesis H1 "Pendidikan mempunyai pengaruh positif dan signifikan terhadap Kinerja karyawan" diterima. (2) Hasil pengujian hipotesis pelatihan menunjukkan nilai $\mathrm{t}$ hitung sebesar 15,847 yang kemudian dibandingkan dengan $\mathrm{t}$ tabel yaitu 1,974, yang berarti bahwa hipotesis dalam penelitian ini menolak $\mathrm{H}_{0}$ dan menerima $\mathrm{H}_{\mathrm{a} 2}$. Dengan demikian dapat disimpulkan bahwa hipotesis H2 "Pelatihan mempunyai pengaruh positif dan signifikan terhadap Kinerja karyawan" diterima. (3) Hasil pengujian hipotesis kompetensi menunjukkan nilai t hitung sebesar 9,733 yang kemudian dibandingkan dengan $t$ tabel yaitu 1,974, yang berarti bahwa hipotesis dalam penelitian ini menolak $\mathrm{H}_{0}$ dan menerima $\mathrm{H}_{\mathrm{a} 3}$. Dengan demikian dapat disimpulkan bahwa hipotesis H3"Kompetensi mempunyai pengaruh positif dan signifikan terhadap terhadap Kinerja karyawan" diterima. (4) Hasil perhitungan statistik menunjukkan nilai F hitung $=106,432$ yang kemudian dibandingkan dengan $\mathrm{F}$ tabel yaitu 2,66, yang berarti bahwa hipotesis dalam penelitian ini menolak $\mathrm{H}_{0}$ dan menerima $\mathrm{H}_{\mathrm{a} 4}$. Dengan demikian dapat disimpulkan bahwa hipotesis H4 "Pendidikan, Pelatihan dan Kompetensi mempunyai pengaruh positif dan signifikan secara simultan terhadap terhadap Kinerja karyawan" diterima
\end{abstract}

\section{Kata kunci : Pendidikan, Pelatihan, Kompetensi, dan Kinerja Karyawan}

\section{ABSTRACT}

This study uses descriptive quantitative survey techniques. Data collection instrument used was a questionnaire enclosed with a Likert scale with a total population of 291 person employee, with a sample of 168 respondent were employee of CV. ENIGMA. Data were analyzed using statistical methods with SPSS versioin 23 for windows.

The result of this study: (1) the results of hypothesis testing showed education t value 6,512 further consultation with the $t$ tabel 1,974 , wich is mean that the hypothesis in this study reject $\mathrm{H}_{\mathrm{o}}$ and accept $\mathrm{H}_{\mathrm{a}}$. Therefore it can be conclude the hypothesis $\mathrm{H1}$ "Education has a positive and significant influence on employee performance" acceptable. (2) the results of hypothesis testing showed work training $\mathrm{t}$ value 15,847 further consultation with the $\mathrm{t}$ tabel 1,974 , wich is mean that the hypothesis in this study reject $\mathrm{H}_{\mathrm{o}}$ and accept $\mathrm{H}_{\mathrm{a}}$. Therefore it can be conclude the hypothesis $\mathrm{H} 2$ "Work training has a positive and significant influence on employee performance" acceptable. (3) the results of hypothesis testing showed competence $t$ value 9,733 further consultation with the $t$ tabel 1,974 , wich is mean that the hypothesis in this study reject $\mathrm{H}_{\mathrm{o}}$ and accept $\mathrm{H}_{\mathrm{a}}$. Therefore it can be conclude the hypothesis $\mathrm{H} 3$ "Competence has a positive and significant influence on employee performance" acceptable. (4) The result of statistical calculation showed $\mathrm{F}$ value $=106,432$ further consultation with the $\mathrm{F}$ tabel 2,66. wich is mean that the hypothesis in this study reject $\mathrm{H}_{\mathrm{o}}$ and accept $\mathrm{H}_{\mathrm{a}}$. Therefore it can be conclude the hypothesis H4 "Education, Training and Competence has a positive and significant influence as a simultaneous on employee performance" acceptable. 


\section{Keywords:Education,Training,Competence,Performance.}

\section{PENDAHULUAN}

\section{A. Latar Belakang}

Kelangsungan hidup sebui perusahaan bergantung pada kualitas di kuantitas sumber daya yang miliki, ba sumber daya alam sebagai bahan bal produksi maupun sumber daya manus sebagai pengelola kegiatan usaha. Kualit yang dimaksud merupakan ukuran sebera] baik mutu karyawan dalam mengerjaki job description yang dimilikinya.

Rendahnya kualitas sumber da: manusia merupakan salah satu fakt penghambat arus kegiatan perusahaan.

Rangkaian perkembangan sains $d_{i}$ teknologi yang disertai dengan mobilit antar bangsa, kini telah meliputi selurı aspek-aspek kehidupan bermasyarakat $d$ bernegara. Dalam perjalananny perkembangan sains dan teknologi ini aki memicu pertumbuhan dan pembangun: nasional. Pembangunan nasional berupa: dalam memperbaiki dan meningkatk: kemampuan tenaga kerja baik dari segi spiritual maupun materiil.

Demi mewujudkan upaya tersebut, diperlukan kesiapan dalam bentuk suatu perencanaan strategis yang terintegrasi guna membangun dan menghadirkan tenaga kerja dengan kompetensi kerja yang layak, dalam bentuk program-program pelatihan yang diselenggarakan oleh negara maupun pihak swasta guna memenuhi kebutuhan pasar tenaga kerja nasional dan internasional.

$$
\text { Soekidjo Notoatmojo (2003:27), }
$$
berpendapat bahwa "pendidikan didalam suatu organisasi merupakan proses pengembangan kemampuan kearah yang diinginkan oleh organisasi bersangkutan".

Berdasarkan definisi diatas, pendidikan bertujuan untuk membawa seorang atau kelompok menjadi pribadi yang lebih bermanfaat dan berwawasan. Pendidikan juga dapat menjadi bekal bagi para sumber daya manusia untuk menghadapi dunia kerja. Kemajuan yang terjadi pada sebuah perusahaan tidak terlepas dari kualitas tenaga kerja yang dimiliki perusahaan tersebut. Konsep pendidikan yang baik akan berpengaruh pada meningkatnya kualitas tenaga kerja, sebaliknya konsep pendidikan yang kurang baik akan berpengaruh pada buruknya kualitas tenaga kerja disebuah perusahaan tempat mereka bernaung.

Pelatihan menurut Djoko Raharjo (2013:73) merupakan "suatu program yang bertujuan untuk menutupi gap antara kecakapan karyawan dengan permintaan jabatan, selain itu juga untuk meningkatkan efisiensi dan efektivitas karyawan dalam mencapai sasaran kerja”. Berdasarkan definisi diatas, pelatihan berkaitan dengan keahlian dan kompetensi karyawan dalam mengerjakan job description yang sedang 
JURNAL ILMIAH

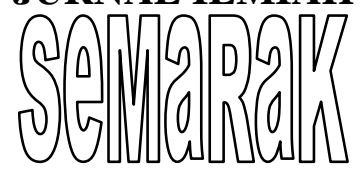

berlangsung sesuai dengan proporsi jabatan yang diemban oleh karyawan didalam perusahaan. Pelatihan yang efektif menyebabkan peningkatan kualitas pekerjaan, produktivitas, loyalitas dan kinerja karyawan.

Wibowo (2012:42), merupakan "kemampuan untuk melaksanakan suatu pekerjaan atau tugas yang dilandasi atas pengetahuan dan keterampilan serta didukung oleh sikap kerja yang dituntut oleh pekerjaan tersebut".

Berdasarkan definisi diatas, kompetensi merujuk pada pengetahuan dan kemampuan seseorang dalam mengelola suatu pekerjaan. Dalam prosesnya, terdap motif yang mendorongtercapainya tuju: secara tepat.

Rivai dan Basri dalam Sinambe (2012:6), "kinerja merupakan hasil at: tingkat keberhasilan seseorang at: kelompok dalam suatu periode terten didalam melaksanakan tugas dibandingki dengan berbagai kemungkinan seperti ha: kerja, target atau kriteria yang teli ditentukan terlebih dahuludan teli disepakati bersama".

Berdasarkan definisi diatas, kiner merujuk pada sebuah ukuran seca kualitatif dan kuantitatif yang menunjuki tingkat pencapaian suatu sasaran at: tujuan yang telah ditetapkan dan dap dihitung serta dapat dijadikan dasar at penilaian akan hasil kerja karyawan ba secara individual maupun team dalam menyelesaikan pekerjaan yang berdasarkan kepada visi dan misi perusahaan.

CV. Enigma adalah sebuah badan usaha yang bergerak dibidang jasa perbaikan, perawatan, dan pengadaan tenaga ahli dibidang mekanik serta penyediaan bahan baku sparepart kendaraan roda empat. Sebagai salah satu perusahaan yang bergerak dibidang jasa, CV. Enigma memiliki visi yaitu menjadi perusahaan yang profesional dengan sumber daya manusia yang berkualitas dan misi yaitu memberikan layanan kendaraan roda empat yang komperhensif.

Karyawan yang memiliki pendidikan terkait disiplin ilmu yang sesuai dengan tugas yang diembannya, merupakan salah satu faktor pendukung tercapainya visi dan misi sebuah perusahaan. Selain itu, ditunjang dengan program pelatihan, guna mengasah kemampuan dan keterampilan sumber daya manusia sehingga perusahaan dapat memiliki tenaga kerja yang kompeten.

Fakta terkait pendidikan pada CV. Enigma adalah bahwa standar pendidikan karyawan belum mendapatkan perhatian secara khusus. Hal ini ditandai dengan ketidak sesuaian disiplin ilmu yang dimiliki oleh karyawan dengan jabatan dan deskripsi kerja yang diembannya.

Berikut merupakan tabel data terkait pendidikan yang diperoleh dari divisi HRD CV. ENIGMA :

Tabel 1.1 
Pendidikan Karyawan CV. Enigma

\begin{tabular}{|c|c|c|c|}
\hline No & $\begin{array}{c}\text { Tingkat } \\
\text { Pendidikan }\end{array}$ & Frekuensi & Persentase ditempat kerja. \\
\hline 1 & SMK/SMA & 284 & $97.59 \%$ \\
\hline 2 & D3 & 1 & terkait kompetensi \\
\hline 3 & S1 & 6 & 2.06\% CV.Enigma adalah bahwa, pengetahuan \\
\hline & TOTAL & 291 & $100.00 \%$ \\
\hline
\end{tabular}

Sumber: Data Primer dari Divisi HRD

CV. Enigma

Berdasarkan data diatas, dapat diperleh informasi mengenai pendidikan terakhir karyawan pada CV. Enigma sebanyak $97.59 \%$ atau 284 karyawan adalah SMA atau sederajat, selanjutnya D3 sebanyak $0.34 \%$ atau 1 karyawan dan sebanyak 6 karyawan atau $2.06 \%$ berijazah $\mathrm{S} 1$. Berdasarkan penjelasan tersebut diatas maka dapat disimpulkan bahwa, tingkat pendidikan karyawan masih terbilang rendah. Hal ini dibuktikan dengan 97.59\% karyawan yang hanya berijazahkan SMA atau SMK.

Fakta terkait pelatihan pada CV. Enigma adalah bahwa perusahaan masih belum menjalankan program pelatihan secara optimal, hal ini ditunjukan dengan belum adanya jadwal dan standar baku resmi terkait pelaksanaan program-program pelatihan, keterbatasan tenaga ahli untuk memberikan pelatihan, keterbatasan fasilitas untuk menunjang program pelatihan serta terdapat kesulitan dalam mengelola peserta yang akan berpartisipasi dalam program pelatihan, hal ini disebabkan oleh tidak berkalanya program pelatihan yang diselenggarakan serta memadai sehingga kerap kali dijumpai adanya kecelakaan dan kesalahan kerja. Kurangnya pemahaman karyawan akan tugas kerja yang dimiliki.

Fakta terkait kinerja pada CV. Enigma adalah bahwa terjadi ketidakstabilan yang ditandai dengan turun naiknya performansi kerja, hal ini dapat diindikasikan oleh adanya keterlambatan pengumpulan laporan hasil kerja dan kehadiran baik saat masuk kerja atau saat istirahat kerja. .

Berdasarkan penjelasan tersebut diatas maka dapat disimpulkan bahwa tingkat ketidakhadiran karyawan masih terbilang cukup tinggi, hal ini ditunjukan dari adanya jumlah absensi kerja yang terjadi selama periode bulan januari hingga maret.

Permasalahan yang terjadi terkait pendidikan pada CV. Enigma adalah terdapat ketidaksesuaian antara latar belakang disiplin ilmu yang dimiliki oleh karyawan dengan jabatan yang dimiliki, hal ini mengakibatkan kesulitan bagi karyawan dalam memahami tugas yang akan dikerjakan serta tingkat pendidikan karyawan yang masih terbilang rendah.

Permasalahan yang terjadi terkait pelatihan pada $\mathrm{CV}$. Enigma adalah kurang lengkapnya materi pelatihan dan instruktur 


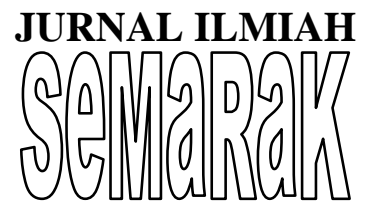

ahli yang disediakan oleh perusahaan dalam meningkatkan kemampuan karyawan. Belum berjalannya metode pelatihan dan pembelajaran kerja yang diterapkan oleh perusahaan kepada seluruh karyawan. Kurang lengkapnya fasilitas kerja yang mendukung proses dan kegiatan pelatihan. Kurangnya kemampuan peserta dalam memahami materi pelatihan.

Permasalahan yang terjadi terkait kompetensi kerja pada CV. Enigma adalahadanya keterbatasan kemampuan yang dimiliki oleh karyawan, kurangnya keterampilan dan insiatif kerja yang dimiliki oleh karyawan dalam menyelesaikan pekerjaan sesuai dengan prosedur kerja yang ada, kurangnya kesadaran akan kemampuan diri sendiri yang dimiliki oleh karyawan.

Permasalahan yang terjadi terkait kinerja adalah laporan hasil kerja yang belum terstruktur, seringnya dijumpai keterlambatan dalam absensi kerja dan pengumpulan laporan, adanya perubahan terkait sistem kerja sehingga menimbulkan perilaku kerja yang tidak efisien. Kreativitas dan inisiatif karyawan dalam bekerja tidak optimal. Tingginya rasa dan sikap individualitas karyawan dalam bekerja.

Berdasarkan teori, fakta dan permasalahan yang telah dipaparkan diatas, maka ditulis penelitian dengan judul “Pengaruh Pendidikan, Pelatihan dan

\section{Kompetensi Terhadap Kinerja Karyawan}

Pada CV. Enigma”.

\section{B. Identifikasi Masalah}

1. Jenjang pendidikan yang dimiliki oleh karyawan dirasa kurang.

2. Belum sesuainya relevansi pendidikan yang dimiliki karyawan dengan tugas kerja yang diemban.

3. Rendahnya jumlah tenaga ahli yang bertugas untuk memberi pelatihan.

4. Belum optimalnya materi pelatihan yang diberikan kepada karyawan.

5. Belum tersusunnya metode pelatihan yang efektif bagi karyawan.

6. Kurangnya pengetahuan karyawan akan tugas kerja yang diberikan.

7. Kurang optimalnya pemahaman karyawan akan prosedur kerja.

8. Kurangnya kesadaran karyawan akan ketepatan waktu dalam bekerja.

9. Kurangnya kemandirian karyawan dalam menyelasaikan tugas.

10. Belum terstrukturnya sistem kerja yang baku pada perusahaan.

\section{Pembatasan Masalah}

1. Tempat penelitian/unit analisis ini adalah CV. Enigma.

2. Karyawan yang dimaksud dalam penelitian ini adalah seluruh karyawan yang bekerja pada CV. Enigma.

3. Pendidikan adalah suatu proses pembelajaran yang diselenggarakan untuk meningkatkan dan mengembangkan seluruh 
potensi yang ada didalam diri seseorang sehingga menjadi individu yang lebih baik.

4. Pelatihan adalah proses pendidikan yang dilakukan secara sistematis untuk meningkatkan mutu sumber daya manusia baik secara pengetahuan, keterampilan maupun sikap yang berorientasi pada kesiapan sumber daya manusia untuk melakukan proses kerja demi tercapainya tujuan perusahaan.

5. Kompetensi adalah abbility yang dimiliki oleh tenaga kerja dalam mengerjakan job desc yang menjadi tanggung jawabnya pada perusahan, yang didasari dengan attitude (motif, sikap dan konsep diri), knowledge (pengetahuan) dan skill (keterampilan) dalam bidang tertentu.

6. Kinerja adalah hasil kerja baik kualitas maupun kuantitas yang berhasil dicapai oleh individu dalam menjalankan tugas dan tanggung jawabnya.

\section{Perumusan Masalah}

1. Seberapa besar pengaruh pendidikan terhadap kinerja karyawan pada CV. Enigma?

2. Seberapa besar pengaruh pelatihan terhadap kinerja karyawan pada CV. Enigma?

3. Seberapa besar pengaruh kompetensi terhadap kinerja karyawan pada CV. Enigma ?

4. Seberapa besar pengaruh pendidikan, pelatihan dan kompetensi secara

\author{
simultan terhadap kinerja karyawan \\ pada CV. Enigma ?
}

\section{E. Tujuan dan Manfaat dari Penelitian}

\section{Tujuan}

a. Untuk mengetahui pengaruh $X_{1}$ terhadap $\mathrm{y}$

b. Untuk mengetahui pengaruh $\mathrm{X}_{2}$ terhadap y

c. Untuk mengetahui pengaruh $\mathrm{X}_{3}$ terhadap y

d. Untuk mengetahui pengaruh $\mathrm{X}_{1}, \mathrm{X}_{2}, \mathrm{X}_{3}$ secara bersama-sama terhadap y

\section{Manfaat}

a. Manfaat Secara Teoritis

Mengetahui lebih dalam tentang indikator yang berpengaruh pada kinerja karyawan.

b. Manfaat Praktis

1) Bagi Perusahaan

a) Sebagai bahan evaluasi bagi manajemen CV. Enigma mengenai variabel yang dibahas dalam penelitian ini.

b) Sebagai bahan rujukan bagi manajemen $\mathrm{CV}$. Enigma dalam menentukan dan merumuskan kebijakan perusahaan khususnya mengenai variabel terkait penelitian.

c)

\section{F. Kerangka Berpikir}

Tirtarahadja(2005:53) berpendapat bahwa, "indikator pendidikan adalah 
JURNAL ILMIAH

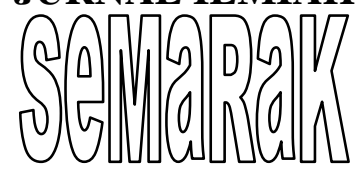

jenjang pendidikan dan kesesuaian jurusan".

Terdapat enam indikator yang menunjang kearah keberhasilan program pelatihan menurut Joko Raharjo (2013:87), antara lain:

1. Tujuan

Diadakannya pelatihan tentu membutuhkan suatu tujuan, terutama penyusunan rencana serta hasil yang diinginkan dari adanya pelatihan.

2. Sasaran

Sasaran harus ditetapkan terlebih dahulu secara measurable.

\section{Trainer}

Dalam melaksanakan pelatihan, trainer yang handal dan berkompeten menjadi salah satu faktor pendukung tercapainya keberhasilan suatu pelatihan.

\section{Materi}

Setelah ditetapkan tujuan, program pelatihan yang baik perlu memperhatikan materi yang akan diberikan. Materi yang dimaksud, harus sesuai dengan kebutuhan karyawan saat melakukan proses kerja di lapangan.

5. Metode

Pemilihan metode yang tepat mampu memberikan dampak yang baik bagi terlaksananya program pelatihan, yakni pelatihan berjalan secara efektif dan efisien.

\section{Peserta}

Selain trainer, dalam melaksanakan pelatihan tentu membutuhkan peserta sebagai objek yang akan dilatih. Peserta pelatihan harus sesuai dengan kriteria yang dibutuhkan. Jika peserta tidak sesuai dengan kriteria yang ada, agar pelatihan dapat berlangsung secara tepat guna.

Spencer and Spencer dalam Tjutju Yuniarsih dan Suwatno (2008:23), berpendapat bahwa ada 5 indikator terkait kompetensi, antara lain:

1. Motif

2. Sifat atau Ciri Bawaan

3. Konsep Diri

4. Pengetahuan

5. Keterampilan

Dessler dalam Narmodo (2010:3), "mengungkapkan bahwa terdapat enam indikator guna mengukur kinerja karyawan yaitu kualitas, kuantitas, ketepatan waktu, efektifitas, kemandirian dan komitmen kerja".

\section{G. Hipotesis}

Hipotesis yang ada pada penelitian ini adalah sebagai berikut :

1. Untuk mengetahui adanya pengaruh yang signifikan antara pendidikan terhadap kinerja karyawan CV. Enigma.

$\mathrm{H}_{0}$ : Tidak terdapat pengaruh signifikan antara pendidikan terhadap kinerja karyawan CV. Enigma.

$\mathrm{H}_{\mathrm{a} 1}$ : Terdapat pengaruh signifikan antara pendidikan terhadap kinerja karyawan $\mathrm{CV}$. Enigma.

2. Untuk mengetahui adanya pengaruh yang signifikan antara pelatihan terhadap kinerja karyawan CV. Enigma.

$\mathrm{H}_{0}$ : Tidak terdapat pengaruh signifikan antara pelatihan terhadap kinerja karyawan CV. Enigma. 


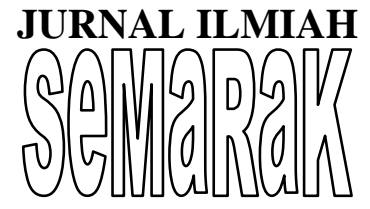

$\mathrm{H}_{\mathrm{a} 2}$ : Terdapat pengaruh signifikan antara pelatihan terhadap kinerja karyawan $\mathrm{CV}$. Enigma.

3. Untuk mengetahui adanya pengaruh yang signifikan antara kompetensi terhadap kinerja karyawan CV. Enigma.

$\mathrm{H}_{0} \quad$ : Tidak terdapat pengaruh signifikan antar kompetensi terhadap kinerja karyawan CV. Enigma.

$\mathrm{H}_{\mathrm{a} 3} \quad$ : Terdapat pengaruh signifikan antara kompetensi terhadap kinerja karyawan CV. Enigma.

4. Untuk mengetahui adanya pengaruh yang signifikan antara pendidikan, pelatihan dan kompetensi terhadap kinerja karyawan CV. Enigma.

$\mathrm{H}_{0} \quad$ : Tidak terdapat pengaruh signifikan pendidikan, pelatihan dan kompetensi secara bersama-sama pada kinerja karyawan CV. Enigma.

$\mathrm{H}_{\mathrm{a} 4} \quad$ : Terdapat pengaruh signifikan antara pendidikan, pelatihan, dan kompetensi terhadap kinerja karyawan CV. Enigma.

\section{II.LANDASAN TEORI}

A. Manajemen Sumber Daya Manusia

1. Pengertian Manajemen

$$
\text { Umi Rusilowati (2013:23), }
$$

mendefinisikan bahwa "manajemen merupakan suatu proses mengkoordinasikan dan mengintegrasikan kegiatan-kegiatan kerja agar diselesaikan secara efisien dan efektif dengan dan melalui orang lain”.

\section{Pengertian Manajemen SDM}

Edy Sutrisno (2011:7), menyatakan bahwa "manajemen sdm merupakan sebuah perencanaan, pengorganisasian, pengarahan dan pengawasan atas pengadaan, pengembangan, kompensasi, pengintegrasian, pemeliharaan, dan pemutusan hubungan kerja yang dimaksudkan untuk pencapaian tujuan sebuah organisasi atau perusahaan".

\section{B. Pendidikan}

\section{Pengertian Pendidikan}

Suherman (2011:54), berpendapat bahwa "pendidikan dapat didefinisikan sebagai proses penyampaian nilai atau tatanan ideal dari pendidik kepada peserta didik dengan tujuan utama agar peserta didik memperoleh IPTEK yang dapat digunakan dalam memenuhi kebutuhan hidup dan kehidupannya".

\section{Pelatihan}

\section{Pengertian Pelatihan}

Menurut T. Hani Handoko (2010:104), berpendapat bahwa "pelatihan dimaksudkan untuk memperbaiki penguasaan berbagai keterampilan dan teknik pelaksanaan kerja tertentu, terinci dan rutin. Latihan menyiapkan para karyawan untuk melakukan pekerjaanpekerjaan sekarang".

\section{Faktor - Faktor Yang Mempengaruhi}

\section{Pelatihan}

Menurut Marwansyah (2014:156), terdapat beberapa faktor yang mempengaruhi pelatihan, yaitu:

a. Dukungan manajemen puncak.

b. Komitmen para spesialis dan generalis dalam pengelolaan SDM.

c. Perkembangan teknologi.

d. Kompleksitas organisasi. 
e. Gaya belajar.

f. Kinerja fungsi-fungsi MSDM lainnya.

D. Kompetensi

\section{Pengertian Kompetensi}

Wibowo (2012:42), bahwa kompetensi adalah "kemampuan untuk melaksanakan suatu pekerjaan atau tugas yang dilandasi atas pengetahuan dan keterampilan serta didukung oleh sikap kerja yang dituntut oleh pekerjaan tersebut”.

\section{E. Kinerja}

\section{Pengertian Kinerja}

Sedarmayanti (2013:260), kinerja adalah "hasil kerja seorang pekerja, sebuah proses manajemen atau suatu organisasi secara keseluruhan, dimana hasil kerja tersebut harus dapat ditunjukan buktinya secara kongkrit dan dapat diukur (dibandingkan dengan standar yang telah ditentukan)".

\section{Faktor - Faktor yang Mempengaruhi} Kinerja

Menurut Dale Timpe dalam Anggraini (2011:40), “terdapat dua faktor yang mempengaruhi kinerja karyawan, yaitu faktor internal dan faktor eksternal".

\section{F. Penelitian Terdahulu}

Penelitian terdahulu bertujuan untuk membersikan masukan dan informasi mengenai penelitian berjudul pengaruh pendidikan, kompetensi, dan motivasi terhadap kinerja.

\section{METODOLOGI PENELITIAN}

\section{A. Ruang Lingkup Penelitian}

1. Tempat Penelitian

Penelitian ini dilaksanakan di CV. Enigma. CV. Enigma merupakan sebuah perusahaan yang menyediakan jasa perbaikan, perawatan, dan pengadaan tenaga ahli dibidang mekanik serta penyediaan bahan baku sparepart kendaraan roda empat.

\section{Waktu Penelitian}

Penelitian ini dilaksanakan pada bulan April - Agustus 2017.

\section{Metode Penelitian}

Metode penelitian yang dipergunakan dalam penelitian ini adalah metode statistik deskriptif dengan pendekatan kuantitatif. Menurut sugiyono (2009:147), "statistik deskriptif adalah statistik yang digunakan untuk menganalisis data dengan cara menjelaskan gambaran data yang telah terkumpul sebagaimana adanya atau aslinya tanpa bermaksud untuk membuat kesimpulan yang berlaku secara umum".

Pendekatan kuantitatif digunakan karena data dalam penelitian ini dinyatakan dalam angka-angka, seperti yang dijelaskan oleh Sugiyono (2009:17), "bila serangkaian observasi atau pengukuran dapat dinyatakan dalam angka-angka, maka kumpulan angkaangka hasil observasi atau pengukuran demikian dinamakan data kuantitatif".

\section{B. Populasi dan Sampel}

\section{Populasi}




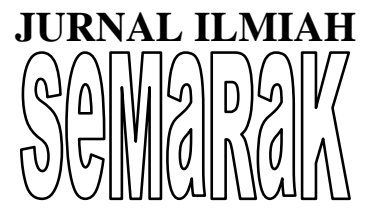

Populasi yang dimaksud dalam penelitian ini adalah karyawan yang bekerja pada CV. Enigma yang berjumlah 291 orang.

\section{Sampel}

Dalam menentukan jumlah sampel yang akan dipilih, penulis menggunakan tingkat kesalahan sebesar 5\%, karena dalam setiap penelitian tidak mungkin hasilnya sempurna $100 \%$, semakin kecil toleransi kesalahan, semakin akurat sampel menggambarkan populasi. Maka sampel yang akan digunakan dalam penelitian ini sebanyak 291orang/responden dengan melakukan penghitungan sebagai berikut:

$$
\begin{aligned}
& \boldsymbol{n}=\frac{\mathrm{N}}{\left(N \cdot e^{2}\right)+1} \\
& \boldsymbol{n}=\frac{291}{\left(291 \cdot 0,05^{2}\right)+1} \\
& \boldsymbol{n}=\frac{291}{0,7275+1} \\
& \boldsymbol{n}=168,45 \\
& \boldsymbol{n}=168 \text { (Pembulatan) }
\end{aligned}
$$

\section{Metode Pengumpulan Data}

Metode pengumpulan data dalam penelitian ini penulis membuat kuesioner dalam bentuk pernyataan untuk disebarkan kepada seluruh karyawan CV. Enigma sebanyak 168 responden sebagai sampel penelitian.

Setelah dilakukan pengisian instrumen (kuesioner) oleh responden, kemudian peneliti mengumpulkan kembali angket yang telah dijawab oleh responden yang kemudian seluruh jawaban responden akan diolah dan dianalisa, berdasarkan jumlah jawaban dari 4 variabel yang diteliti yaitu Pendidikan $\left(\mathrm{X}_{1}\right)$, Pelatihan $\left(\mathrm{X}_{3}\right)$,Kompetensi $\left(\mathrm{X}_{3}\right)$, dan Kinerja (Y) dalam bentuk angka.

\section{Metode Analisis Data}

Agar suatu data yang terkumpul dapat bermanfaat dalam suatu penelitian, maka perlu dilakukan sebuah analisis data, selanjutnya dalam melakukan perhitungan analisis data terkait penelitian ini penulis menggunakan bantuan program Statistical Package for Social Science (SPSS) for windows versi 23.

Bantuan program statistik tersebut digunakan untuk mengetahui skor hasil pengaruh pendidikan, pelatihan dan kompetensi terhadap kinerja karyawan pada CV. Enigma baik secara parsial maupun simultan.

\section{PEMBAHASAN HASIL PENELITIAN}

\section{A. Gambaran Umum Objek Penelitian}

CV. Enigma dimulai pada tahun 2010, diawali dengan berdirinya perusahaan di wilayah jakarta selatan, seiring dengan berjalannya waktu kemudian CV. Enigma berpindah lokasi ke daerah tanggerang selatan, tepatnya di jalan pondok cabe raya no. 100, ciputat tanggerang selatan.

CV. ENIGMA merupakan salah satu badan usaha yang bergerak dibidang pelayanan jasa perbaikan dan perawatan kendaraan roda empat, secara khusus CV. Enigma juga bergerak dibidang pengadaan jasa untuk agen tunggal pemegang merk (ATPM). Terkait 


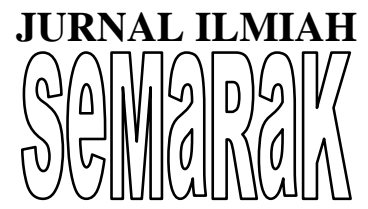

operasional kerja dalam memenuhi kepuasan pelanggannya, CV. Enigma didukung oleh fasilitas peralatan kerja yang berteknologi canggih guna memenuhi standar layanan dan kepuasan bagi para konsumennya, disamping itu CV. Enigma juga didukung oleh kulitas sumber daya manusia yang memiliki pengalaman dan kompetensi dibidangnya serta manajemen yang aktif, kreatif dan berintegritas tinggi dalam mengelola dan memajukan perusahaan.

\section{Visi}

Menjadi perusahaan terdepan dalam layanan kendaraan roda empat yang berkualitas

\section{Misi}

Memberi pelayanan kendaraan roda empat secara komperhensif

\section{B. Karakteristik Responden}

Responden dalam penelitian iniadalah karyawan yang bekerja pada CV. ENIGMA yang berjumlah 168 orang karyawan, selanjutnya untuk mempermudah penelitian ini, penulis mengelompokan data responden berdasarkan beberapa kategori seperti usia, jenis kelamin, tingkat pendidikan, dan masa kerja.

\section{Hasil Uji Instrumen}

\section{Uji Validitas dan Reliabilitas}

Untuk mengetahui sejauh mana alat ukur mampu mengukur apa yang ingin diukur, digunakan uji validitas. Uji validitas dilakukan dengan cara menghitung korelasi antara skor masing-masing item dengan skor total menggunakan teknik korelasi pearsonproduct moment.

Untuk melakukan pengujian sejauh mana kehandalan suatu alat ukur di dalam penelitian, maka digunakan uji reliabilitas didalam penelitian ini. "Suatu variabel dikatakan realible jika memiliki nilai cronbach alpha diatas 0,60". Ghozali, (2005:62).

Berdasarkan uji validitas dan reliabilitas pada penelitian yang penulis lakukan, seluruh butir pernyataan pada variabel pendidikan, pelatihan, kompetensi, dan kinerja dinyatakan valid dan reliabel.

\section{Hasil Uji Regresi Sederhana}

Uji analisis regresi sederhana digunakan untuk mengetahui seberapa besar pengaruh parsial variabel bebas terhadap variabel terikat. Hasil perhitungan uji regresi sederhana adalah sebagai berikut :

a. Variabel pendidikan (X1) berpengaruh postif terhadap variabel kinerja $(\mathrm{Y})$ dengan perolehan nilai koefesien sebesar 0,451.

b. Variabel pelatihan (X2) berpengaruh postif terhadap variabel kinerja (Y) dengan perolehan nilai koefesien sebesar 0,776.

c. Variabel kompetensi (X3) berpengaruh postif terhadap variabel kinerja (Y) dengan perolehan nilai koefesien sejumlah 0,603 .

\section{Hasil Uji Regresi Berganda}

Untuk mengetahui besar pengaruh variabel $\mathrm{X} 1, \mathrm{X} 2, \mathrm{X} 3$ secara simultan terhadap variabel y maka dilakukan uji regresi berganda, sehingga dapat diketahui apakah 


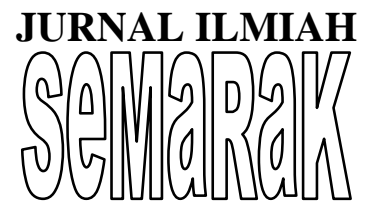

ketiga variabel bebas tersebut berpengaruh positif atau negatif terhadap terhadap variabel terikat yaitu kinerja.

Berdasarkan hasil perhitungan uji regresi berganda, persamaan yang terbentuk sebagai berikut:

$Y=0,524-0,26 \times 1+0,653 \times 2+0,275 \times 3$

\section{KESIMPULAN DAN SARAN}

\section{A. Kesimpulan}

1. Pendidikan mempunyai pengaruh positif terhadap kinerja karyawan pada $\mathrm{CV}$. Enigma. Hal ini dibuktikan dengan t hitung senilai 6,512 > nilai t tabel yaitu 1,974 dengan taraf signifikansi $(\mathbf{0 , 0 0 0 )}<$ dari $(\mathbf{0 , 0 5})$. Selanjutnya, persamaan regresi sederhana yang terbentuk yaitu $Y=\mathbf{1 8 , 8 1 6}$ $+\quad 0,451 \quad X 1$. Persamaan tersebut memberikan informasi bahwa nilai kinerja yang terbentuk adalah 18,816 dan setiap terjadi peningkatan satu satuan variabel pendidikan akan dapat mengakibatkan peningkatan nilai kinerja sebesar $\mathbf{0 , 4 5 1}$.

2. Pelatihan berpengaruh positif terhadap kinerja pada CV. Enigma. Hal ini dibuktikan dengan t hitung senilai 15,847 > nilai t tabel yaitu 1,974 dengan taraf signifikansi $(\mathbf{0 , 0 0 0 )}<$ dari $(\mathbf{0 , 0 5})$. Selanjutnya, persamaan regresi sederhana yang terbentuk yaitu $Y=4,680+0,776 X 2$. Persamaan tersebut memberikan informasi bahwa nilai kinerja yang terbentuk adalah 4,680 dan setiap terjadi peningkatan satu satuan variabel pelatihan akan dapat mengakibatkan peningkatan nilai kinerja sebesar $\mathbf{0 , 7 7 6 .}$

3. Kompetensi memiliki pengaruh yang positif terhadap kinerja karyawan pada CV. Enigma. Hal ini dibuktikan dengan $\mathbf{t}$ hitung sebesar 9,733 > nilai t tabel yaitu 1,974 dengan taraf signifikansi (0,000) lebih kecil dari (0,05). Selanjutnya, persamaan regresi sederhana yang terbentuk yaitu $Y=11,227+0,603 X 3$. Persamaan tersebut memberikan informasi bahwa nilai kinerja yang terbentuk adalah 11,227 dan setiap terjadi peningkatan satu satuan variabel kompetensi akan dapat mengakibatkan peningkatan nilai kinerja sebesar $\mathbf{0 , 6 0 3}$.

4. Pendidikan, Pelatihan dan Kompetensi berpengaruh positif terhadap Kinerja karyawan pada CV. Enigma. Hal ini dapat dilihat berdasarkan hasil uji $\mathrm{F}$ dimana diperoleh nilai F hitung sebesar 106,432 > nilai F tabel yaitu 2,66 dengan taraf signifikansi $(\mathbf{0 , 0 0 0})$ lebih kecil dari $(\mathbf{0 , 0 5})$. Selanjutnya, persamaan regresi berganda yang terbentuk yaitu $Y=0,524-0,26 X 1+$ $0,653 X 2+0,275 X 3$. Persamaan tersebut memberikan informasi bahwa nilai kinerja yang terbentuk adalah $\mathbf{0 , 5 2 4}$ dan setiap terjadi peningkatan satu satuan variabel pendidikan tidak mempengaruhi variabel kinerja.Selanjutnya, setiap terjadi peningkatan satu satuan variabel pelatihan akan dapat mengakibatkan peningkatan nilai kinerja sebesar $\mathbf{0 , 6 5 3}$. Kemudian, setiap terjadi peningkatan satu satuan 
JURNAL ILMIAH

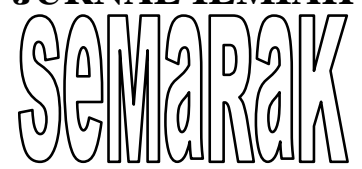

variabel kompetensi akan dapat mengakibatkan peningkatan nilai kinerja sebesar $\mathbf{0 , 2 7 5}$.

B. Saran

1. Berdasarkan distribusi jawaban responden untuk variabel pendidikan perlu kiranya pihak manajemen CV. Enigma, lebih memperhatikan relevani antara latar belakang pendidikan karyawan dengan jabatan yang diemban, guna mencapai proses kerja yang efektif dan efisien karena karyawan mampu mengaplikasikan ilmu yang dimiliki dari bangku sekolah kedalam pekerjaan yang menjadi tanggung jawabnya.

2. Berdasarkan distribusi jawaban responden untuk variabel pelatihan, sekiranya pihak manajemen $\mathrm{CV}$. Enigma dapat membuat program-program pelatihan secara terstruktur dan terukur yang ditunjang dengan ketersediaan tenaga pelatih yang berkompeten dibidangnya untuk meningkatkan kemampuan dan kinerja yang dimiliki karyawan.

3. Berdasarkan distribusi jawaban responden untuk variabel kompetensi perlu kiranya pihak manajemen memperhatikan sop yang sudah dibuat agar karyawan memiliki dasar dalam melaksanakan pekerjaannya.

4. Berdasarkan distribusi jawaban responden untuk variabel kinerja. Perlu kiranya bagi pihak CV. Enigma untuk meningkatkan faktor-faktor yang dapat meningkatkan kinerja karyawan reward dan punisment. Dengan adanya reward dan punisment

\begin{abstract}
diharapkan dapat meminimalisir terjadinya ketidak efesiensi dan efektivitas pegawai, baik berupa waktu ataupun pemakaian fasilitas yang mendukung pekerjaan yang telah disediakan oleh organisasi.
\end{abstract}

\section{DAFTAR PUSTAKA}

Adang, Suherman, 2011, Penelitian Pendidikan, Universitas Pendidikan Indonesia, Bandung.

Anggraini, Ririn Dwi, 2011, Pengaruh Kepemilikan Institusional danKepemilikan Asing Terhadap Pengungkapan Pertanggung jawaban Sosial Perusahaan dalam Annual Report (Studi Empiris Pada Perusahaan Non Keuangan yang Tercatat Di BEI.

Ghozali, Imam, 2005, Aplikasi Analisis Multivariate dengan Spss, Badan Peneliti UNDIP, Semarang.

Handoko, T. Hani. 2010, Manajemen, Cetakan Dua puluh, BPEE, Yogyakarta.

Hasbullah, 2005, Dasar-Dasar Ilmu Pendidikan, PT. Raja Grafindo Persada, Jakarta.

2008, Dasar-Dasar Ilmu Pendidikan, PT. Raja

Grafindo Persada, Jakarta

Hasibuan, Malayu S.P, 2006. Manajemen Dasar, Pengertian, dan Masalah,EdisiRevisi, Bumi Aksara, Jakarta.

2012. Manajemen Sumber Daya

Manusia, Bumi Aksara, Jakarta.

Hermowo, Narmodo, 2010, Pengaruh Motivasi Kerja dan Disiplin KerjaTerhadap Kinerja Pada Karyawan BNI di Daerah Kudus. 
JURNAL ILMIAH

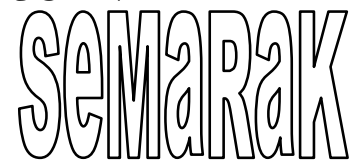

INPRES Nomor 6 tahun 2014 Tentang

Peningkatan Daya Saing Nasional.

Http://hdr.undp.org, Data Human Development

Index, 2015.

Kuneifi, Amin, 2016, MSDM: Evaluasi

Kinerja Karyawan, Bagaimana Agar

Organisasi dan Karyawan Tumbuh Secara

Seimbang, Pe\#koPers, Tanggerang Selatan.

Marwansyah. 2014.Manajemen Sumber Daya

Manusia, Alfabeta, Bandung. Notoadmodjo,

Soekidjo, Prof, DR,2003, Pengembangan

Sumber Daya Manusia, Rineka Cipta, Jakarta.

Tirtarahardja, Umar, 2005, Pengantar

Pendidikan, Rineka Cipata, Jakarta. Raharjo,

Joko, 2013, Paradigma Baru Manajemen

Sumber Daya Manusia KunciSukses

Meningkatkan Kinerja, Produktivitas,

Motivasi, dan Kepuasan Kerja, Platinum,

Tanggerang.

Rivai, Veithzal, 2011 Manajemen Sumber

Daya Manusia Untuk Perusahaan: dariTeori

ke Praktik, Raja Grafindo Persada, Jakarta.

Rusilowati, Umi, 2013. "Manajemen

Pengetahuan Berbasis Teknologi

InformasiDalam Konteks Pembelajaran

Organisasi”, CV Asmoro Mediatama,

Tangerang Selatan.

Sedarmayanti, 2013, Manajemen Sumber Daya

Manusia, Refika Aditama, Bandung.

Sinambela, Poltak Lijan, 2012, Kinerja

Pegawai Teori Pengukuran dan Implikasi,

Graha Ilmu, Yogyakarta.

Sugiyono, 2009, Metode Penelitian Bisnis (Pendekatan Kuantitatif, Kualitatif,dan R\&D),

Alfabeta, Bandung.
Sutrisno, Edy, 2011,Manajemen Sumber Daya Manusia, Kencana, Jakarta.

Tjutju Yuniarsih dan Suwatno, 2008, Manajemen Sumber Daya Manusia,Alfabeta, Bandung.

Undang-Undang Republik Indonesia No.13

Tahun 2003 tentang ketenaga kerjaan.

Wibowo. 2010. Manajemen Kinerja,Edisi

Ketiga.Rajawali Pers, Jakarta . 2012. Manajemen Kinerja Jakarta :

Rajawali Pers. 